\title{
The academic model of managing integration processes: study case of the multicultural educational space
}

\author{
Elmira R. Vasilyeva ${ }^{1 *}$, Aida R. Nurutdinova ${ }^{2}$ \\ ${ }^{1}$ Ufa State Petroleum Technological University, Branch of the University in the City of Oktyabrsky, Russian Federation \\ ${ }^{2}$ University of Management «TISBI», Kazan, Russian Federation
}

\begin{abstract}
Improvement and preconditions for multicultural education are associated with the democratic society development which is characterized by openness to other countries, peoples and cultures. Mutual understanding is its most important value. The ongoing integration processes in the world, the desire of Russia and other countries to integrate into the world and European sociocultural and educational space, while preserving the national identity, determines the multicultural education development. Education in a multicultural society, according to experts, is associated with the optimal models of the educational process, various methods and technologies of educational activities. They really include students in the multicultural educational space, they form the qualities necessary for successful adaptation and self-realization in the modern world.
\end{abstract}

\section{Introduction}

Transformation of the management system in education is significantly modernised by the educational policy at the regional level. New deliberate strategies in the development of economic, political, sociocultural spheres, increased the society openness, its rapid informatization and dynamism cause the certain change in the state requirements for the education. Those changes are largely related to the formation of the multicultural space, the preservation of their cultural and national identity and respect for another cultural and ethnic community. Education fulfils the mission of the most important state institution that consolidates the nation and forms the all-Russian identity of citizens only if the educational policy is based on the principle of integrating all processes related to the education and children and adolescents upbringing [2].

\section{Results and discussion}

Multiculturalism in the educational space among the other coordinates of the system-forming ones. The term "polycultural educational region" is treated by A.A. Shogenov as a specific part of the federal educational space, which has relative integrity in the sphere of education (political, administrative, resource, social and pedagogical). The socio-pedagogical specifics of the region are based on the ethnic and pedagogical foundations. The tasks for modernization in the education of the multicultural region can be solved only on the basis of the assessment of the management effectiveness at the educational institution. Assessment of the effectiveness is one of the key problems in the management practice, in the formation and implementation of educational policies. The need for quality expert procedures increases with the innovations development in the education area [1-4]. Responsibility for the education's quality in our country has always been assigned to state educational authorities.

\subsection{The indicators for effective multicultural orientation}

The national infrastructure of the education quality assessment system has several organisational levels:

- Federal;

- Regional;

- Municipal;

- The educational institution itself.

At the same time, each of these levels solves the crosscutting issues that provide the federal vertical and the tasks of its own level in assessing the quality of the educational services provided, it should be noted that the activity of the educational institution is, in this case, the object of assessment [8]. In order for this activity to meet the high level of requirements, it is necessary to organize the system of the educational institutions' functioning and development in the certain way, i.e., to manage the processes in order to meet the level of requirements for their quality [5].

It should be noted that at present the process of managing the education quality is carried out mainly on the basis of analytical activities that don't fully correlate with the accreditation indicators [3]. One of the reasons for this

* Corresponding author: elmira-vasilyeva@ mail.ru 
situation is that educational institutions don't have the necessary integrated quality model corresponding to accreditation indicators. When conducting the examination in the specific areas and education technologies, experts are often guided by "different initial assumptions" [12], which often leads to mutually exclusive conclusions on the same material assessment. The effectiveness of development the multicultural orientation in the educational institution is determined by the following indicators [11]:

- positive changes in the internal and external environment of the multicultural educational system;

- an innovative development model of a multicultural educational institution;

- professional development of pedagogical staff in the field of multicultural education;

- positive development dynamics of students, reflecting their involvement in the multicultural environment;

- positive parents' attitude towards the results of the multicultural activity at the educational institution.

To analyse the effectiveness of quality management in education, it is necessary to compare the quality management processes at the input and output. Inputs of management processes should include prospects and results [10].

\subsection{The existing contradictions and pedagogical conditions}

The management effectiveness of the educational institution in a multicultural environment acquires special significance. Aspects in which the problems of multicultural education are studied are extremely multifaceted and diverse [6]. The cultures' heterogeneity, the existence of special integrative tasks of the educational institution in a multi-ethnic society, the complexity, and multifacetedness of the multicultural-oriented personality formation require a state approach to the creation of the effective system for managing multicultural educational institutions.

The peculiarity of the historical situation in the republic, which is a multicultural and multi-ethnic region, initiates new goals and objectives of education, the decision of which largely depends on the educational process management [9]. The principle of multiculturalism has allowed to expand existing ideas about the management of the educational institution that fosters the formation of students' understanding of the cultures diversity in the world and in their country, the positive development, tolerant attitude to cultural differences, the skills' development, productive interaction with carriers of other cultures.

The analysis of the conducted researches in the management of innovative activity at educational and educational practice has allowed allocating objectively existing contradictions:

- between the need for an effectively functioning system for managing innovation processes in an educational multicultural space and the multicultural orientation in the accreditation of educational institutions;

- between the importance of improving the management quality and insufficient knowledge of the organizational and pedagogical conditions that ensure it in the context of the multicultural orientation development in the educational institution.

The revealed contradictions served as the basis for determining the research problem, the essence of which lies in the justification and development of the organizational and pedagogical conditions for the effective management development at the educational institution with the multicultural orientation.

The main organizational and pedagogical conditions for the development of an educational institution with a multicultural orientation are:

- development of criteria for the educational institution's activity in accordance with accreditation indicators;

- transition to designing the educational management based on the multicultural orientation in education;

- pedagogical monitoring implementation, which allows timely detection and correction of possible deviations in the management course.

\subsection{The organisational structure for educational supervision and control service}

Integration processes are characteristic of the educational space of a multicultural region. Integration is lat. integratio - restoration, replenishment, from integer - the whole is most often understood as the development process, the result of which is the achievement of unity and integrity within the system, based on the interdependence of individual specialized elements.

The organizational and pedagogical conditions for the integration processes provision as the factor in the development of the educational space of a multicultural region include regulatory, legal, program-technological and personnel support [7]. The results of this research can be used as the basis for the educational policies formation in multicultural regions.

The organizational structure of the educational supervision and control service should be such as to ensure its strategy implementation. As the strategies change over time, the organizational structures might need to be changed accordingly. We distinguish several stages in the service development, in which, depending on the purposes and tasks, organizational structures are formed.

First stage. When creating a new service, its tasks, as a rule, are quite extensive: the supervision implementation and control over compliance with the legislation of the Russian Federation in the field of education. One person - the head manages all the service activities. 
Second phase. At the second stage, when the administrative service regulations are being implemented, the work of its management is complicated, since the organization of various activities requires constant attention, namely:

1) work with appeals of individuals and legal entities on the issue of legislation violation in the field;

2) preparation and carrying out of checks, check results processing;

3) control over the orders' implementation, including the taking of measures in connection with prescriptions non-enforcement;

4) preparation on the basis of quarter and year results of analytical materials on the implementation of legislation in the education field.

Deputy managers take over the management of functional units, the main task of the service head is the coordination of their activities.

The third stage is connected with its access to the region. At this stage, in the functional duties of the employees, appears as the activity of "supervision of a particular area".

The fourth stage is related to the expansion of the activity in order to monitor the quality of educational services. The creation of a public council for quality.

The fifth stage is connected with the strategic task's implementation, which requires a more complex organizational structure. It is organized according to the principle of the vertically integrated system.

\section{Conclusions}

The most important aspect in the multicultural education management on the basis of state-public partnership is the quality council creation for the transition to a more complex organizational structure based on the vertically integrated assessment principle of the regional education system .

Integration processes in the educational space of a multicultural region are considered as a priority area for the development of the regional education system. In the course of research work, a theoretical model of managing integration processes as a factor in the development of the educational space of a multicultural region was formed on the basis of:

- state-public partnership in the form of the Quality Council in the service of supervision and control;

- creation of a vertically integrated system for supervision in the field of education;

- quality criteria development for assessing the activities of an educational institution in accordance with accreditation indicators.

\section{References}

1. L. Nazarenko, Procedia - Social and Behavioral Sciences, $\quad \mathbf{1 8 0} \quad$ (2015) DOI: 10.1016/j.sbspro.2015.02.137

2. N. Pogukaeva, N.Pankova, E.Syryamkina, M.Khaldeeva, A.Pogukaeva, Hermeneutic Approach, Inted $2017 \quad$ Proceedings (2017) DOI: $\underline{10.21125 / \text { inted.2017.0735 }}$

3. N. Murray, International Journal for Academic Development, $21, \quad 3016$ DOI: $10.1080 / 1360144 X .2015 .1094660$

4. R.M. Shaidullina, A.F. Amirov, V. S. Muhametshin, K.T. Tyncherov, European Journal of Contemporary Education, 6, 1 (2017) DOI: $10.13187 /$ ejced.2017.1.149

5. C. Nieto, M.Z. Booth, Journal Of Studies In International Education, 14, 4, (2010) DOI: $10.1177 / 1028315309337929$

6. O.V. Gukalenko, V.P. Borisenkov, EEIA-2016, 29 (2016) DOI:10.1051/shsconf/20162901026

7. C. Stokke, L. Lybaek, Ethnicities, 18, 1 (2018), https://doi.org/10.1177/1468796816674504

8. R. M. Amthor, K. Roxas, Teaching and Teacher Education 42 DOI: $10.1016 /$ j.tate.2014.04.008

9. A. S. Ruiz, Journal of Multicultural Counseling and Development, 18, 1 (1990) https://doi.org/10.1002/j.2161-1912.1990.tb00434.x

10. M. Barbosa, Teoria De La Educacion, 23, 2 (2011)

11. G.F. Melnikova, S.I. Gilmanshina, ISTC-IETEM, 240 (2017) DOI: 10.1088/1757-899X/240/1/01205

12. M.Ya. Khabibullin, R.I. Suleimanov, D.I. Sidorkin, I.G. Arslanov, Chemical and Petroleum Engineering, 53, 5-6 (2017) https://doi.org/10.1007/s10556-017-0350-6 